\title{
The role of the Wnt signaling pathway in cancer stem cells: prospects for drug development
}

\author{
This article was published in the following Dove Press journal: \\ Research and Reports in Biochemistry \\ 31 July 2014 \\ Number of times this article has been viewed
}

\author{
Yong-Mi Kim' \\ Michael Kahn ${ }^{2,3}$ \\ 'Children's Hospital Los Angeles, \\ Division of Hematology and \\ Oncology, Department of Pediatrics \\ and Pathology, ${ }^{2}$ Department of \\ Biochemistry and Molecular Biology, \\ Keck School of Medicine of University \\ of Southern California, ${ }^{3}$ Norris \\ Comprehensive Cancer Research \\ Center, University of Southern \\ California, Los Angeles, CA, USA
}

\begin{abstract}
Cancer stem cells (CSCs), also known as tumor initiating cells are now considered to be the root cause of most if not all cancers, evading treatment and giving rise to disease relapse. They have become a central focus in new drug development. Prospective identification, understanding the key pathways that maintain CSCs, and being able to target CSCs, particularly if the normal stem cell population could be spared, could offer an incredible therapeutic advantage. The Wnt signaling cascade is critically important in stem cell biology, both in homeostatic maintenance of tissues and organs through their respective somatic stem cells and in the CSC/ tumor initiating cell population. Aberrant Wnt signaling is associated with a wide array of tumor types. Therefore, the ability to safely target the Wnt signaling pathway offers enormous promise to target CSCs. However, just like the sword of Damocles, significant risks and concerns regarding targeting such a critical pathway in normal stem cell maintenance and tissue homeostasis remain ever present. With this in mind, we review recent efforts in modulating the Wnt signaling cascade and critically analyze therapeutic approaches at various stages of development.
\end{abstract}

Keywords: beta-catenin, CBP, p300, wnt inhibition

\section{Introduction}

Drug resistance, disease relapse, and metastasis constitute the central challenges in the management of advanced malignancies. Recently, cancer initiation, metastasis, and disease progression have been attributed to newly discovered subpopulations of self-renewing, highly tumorigenic, drug-resistant tumor cells termed cancer stem cells (CSCs), also known as tumor initiating cells (TICs). ${ }^{1}$ In many ways, CSCs behave very similarly to their normal counterparts, the somatic stem cells (SSCs), in that they have the ability to both self-renew and also to proceed on to more differentiated cell types. SSCs reside in specialized niches within tissues or organs (eg, hematopoietic stem cells, neuronal stem cells, and intestinal stem cells) and are critical for both normal tissue homeostasis and regeneration after injury. ${ }^{2-4} \mathrm{~A}$ major focus in cancer research over the past decade has been to both prospectively identify CSCs and, even more critically, to develop therapeutic strategies to safely eliminate this cell population without deleterious effects to the normal SSC populations.

A critical hurdle to safely accomplish this goal is the identification of key mechanisms that distinguish the control of self-renewal and proliferation of CSCs from their normal endogenous SSC counterparts. Not surprisingly, the same evolutionarily conserved signaling pathways that govern embryonic development are also critical to control the behavior of both normal somatic stem cells as well as cancer stem cells. The Wnt/ $\beta$-catenin, ${ }^{5,6}$ Hedgehog, ${ }^{7}$ and Notch $^{8}$ pathways have all 
been implicated in stem cell and cancer stem cell biology. In this review, we will focus on the role of the Wnt signaling cascade in CSCs and the prospects for safely and effectively targeting this cascade to eliminate the CSC population in cancer.

\section{Cancer stem cells and their role in tumorigenesis}

Almost 150 years ago, Cohnheim ${ }^{9}$ proposed the concept that cancer might arise from a rare population of cells with stem cell-like properties. Today, increasing evidence has confirmed the existence of a small subgroup of cells in cancer, termed CSCs or, alternatively, TICs. The presence of CSCs has forced a paradigm shift from the earlier model of tumor homogeneity toward one of tumor hierarchy, where CSCs play a critical role. ${ }^{10}$ The cancer stem cell concept postulates that the bulk of a tumor consists of rapidly proliferating and differentiated (albeit aberrantly or only partially differentiated) cells, with a small population of CSCs that provide for the long-term maintenance of the tumor. These cells are able to self-renew, ${ }^{11}$ actively express telomerase, ${ }^{12}$ and activate antiapoptotic and multidrug resistance pathways. CSCs are relatively quiescent but can give rise to rapidly dividing progeny (so called transient amplifying cells), which form the bulk of tumor cells. Endowed with these characteristics, CSCs are thought to be responsible for tumor initiation, progression, and relapse, as well as metastasis and drug resistance. ${ }^{13,14}$ Supporting evidence exists that a stem-like signature contributes to aggressiveness and is related to poor outcome. ${ }^{15}$ Although CSCs resemble tissue stem cells in several characteristics, such as self-renewal and differentiation potential, it has been pointed out that the term "cancer stem cell" does not necessarily refer to the cell of origin, but can also refer to more differentiated cells that have acquired stem-like properties. ${ }^{16}$ Despite a still existing although decreasing controversy regarding the CSCs hypothesis, ${ }^{17}$ it is clear that distinct cancer cell populations have enhanced tumorigenic capacity compared with bulk tumor cells. Findings of cancer cells with enhanced tumor initiating properties were initially reported in leukemia. Bruce and van der Gaag $^{18}$ demonstrated that only a small subgroup of cells showed extensive proliferation in vivo and in vitro. In 1997, Bonnet and Dick ${ }^{19}$ first isolated CSCs (known as leukemic stem cells, or LSCs) from bulk acute myeloid leukemia cells. Leukemic stem cells maintained or reacquired the ability to proliferate indefinitely, while losing the ability to properly differentiate. ${ }^{20}$ Subsequently, over the past decade, a large number of studies have identified CSCs in multiple solid tumors, including brain tumors, ${ }^{21}$ melanoma, ${ }^{22}$ and breast, ${ }^{23}$ liver, ${ }^{24}$ pancreatic, ${ }^{25}$ and colon cancer. ${ }^{26}$

\section{Wnt signaling in embryonic development and homeostasis}

The Wnt/ $\beta$-catenin pathway initiates a signaling cascade critical in both normal embryonic development and throughout the life of the organism in virtually every tissue and organ system. It is an enormously complex and ancient pathway that dates back to the first anaerobic metazoans. In addition to classical "canonical" Wnt activation of $\beta$-catenin/T-cell factor (TCF) transcriptional complexes, Wnt proteins can elicit a variety of alternative responses, often grouped together as "noncanonical" Wnt signaling. ${ }^{27}$

Wnts are secreted cysteine-rich glycoproteins that act as short-range ligands to locally activate receptor-mediated signaling pathways. ${ }^{28}$ The hallmark of this pathway is that it activates the transcriptional role of the multifunctional protein $\beta$-catenin. The key mediator of Wnt signaling, the armadillo protein $\beta$-catenin, dynamically localizes to multiple subcellular locations, including adherens junctions where it contributes to cell-cell contacts, the cytoplasm where $\beta$-catenin levels are tightly controlled, and the nucleus where in the canonical Wnt signaling pathway, $\beta$-catenin is involved in transcriptional regulation and chromatin modifications. ${ }^{29,30}$ The cytoplasmic pool of $\beta$-catenin is tightly regulated via phosphorylation by the "destruction complex" that includes glycogen synthase kinase $3 \beta$, casein kinase $1 \alpha$, the scaffold protein Axin, and the tumor suppressor adenomatous polyposis coli (APC), among others ${ }^{31}$ (Figure 1A). In the absence of Wnt signaling, phosphorylation marks cytoplasmic $\beta$-catenin for ubiquitination and proteasomal degradation. A key step in the activation of Wnt target genes is the formation of a complex between $\beta$-catenin and members of the TCF/lymphoid enhancer factor family of transcription factors. To generate a transcriptionally active complex, TCF/ $\beta$-catenin recruits the KAT3 transcriptional coactivator CREB-binding protein (CBP) (where CREB is an abbreviation for cAMP-response element binding protein), or its closely related homolog p300, as well as other components of the basal transcription machinery, to initiate transcription (Figure 1B).

The canonical, $\beta$-catenin-dependent Wnt signaling pathway plays crucial roles in the regulation of diverse cellular behaviors, including cell fate, proliferation, and survival. However, there exists a second noncanonical pathway, whose major effects apparently are $\beta$-catenin-independent in at least as much as that there is no apparent stabilization of cytoplasmic $\beta$-catenin. The noncanonical pathway is more 

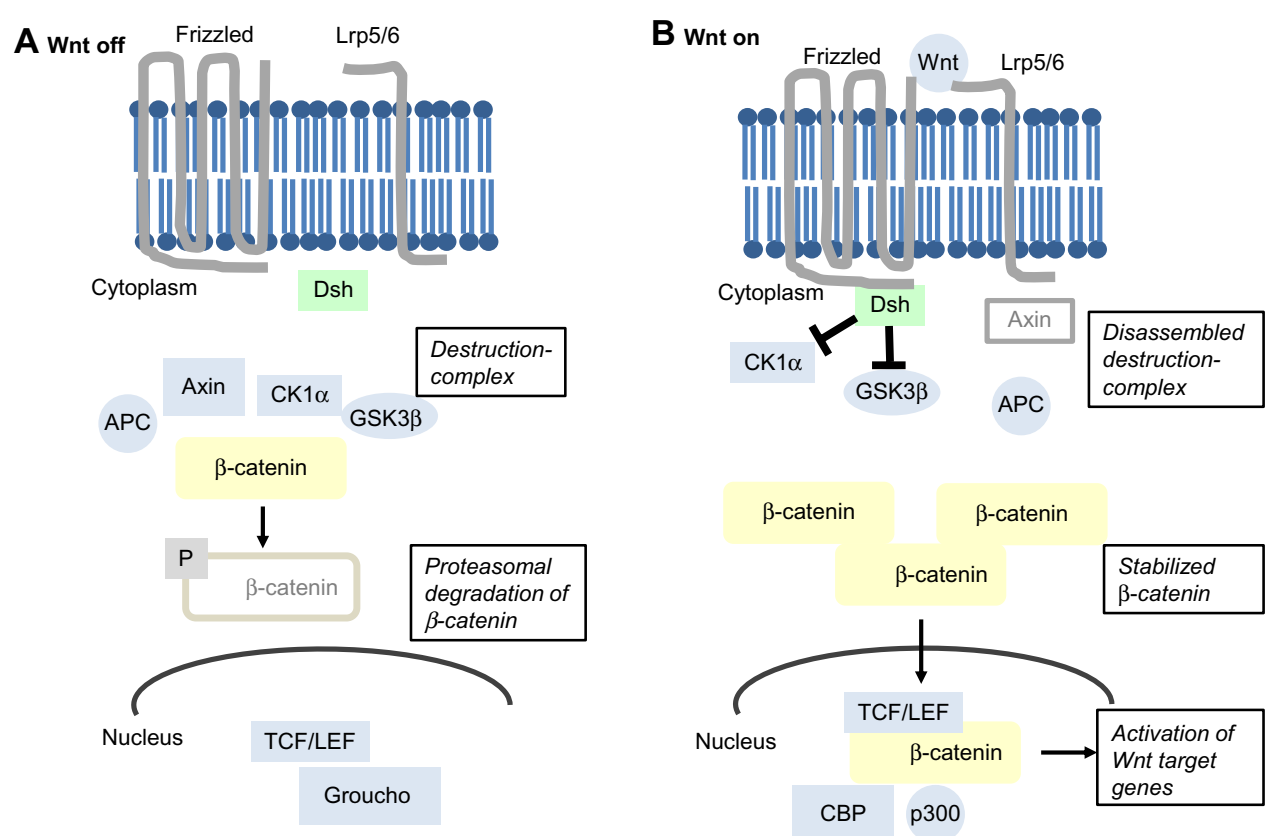

Figure I Canonical Wnt signaling.

Notes: (A) Wnt off. In the absence of Wnt (Wingless) ligands, a multi-protein destruction complex in the cytoplasm consists of Axin-I and its interacting partners tumor suppressor adenomtous polyposis coli (APC), glycogen synthase kinase $3 \beta$ (GSK3 $\beta$ ), and casein kinase I $\alpha$ (CKI). The destruction complex degrades $\beta$-catenin by proteasomal degradation via phosphorylation and, thus, maintains low levels of $\beta$-catenin. (B) Wnt on. In the presence of Wnt ligand binding to the frizzled/Lrp5/6 (low density lipoprotein receptor-related proteins 5 or 6 ) receptors a negative regulator of the destruction complex, dishevelled (Dsh) is recruited leading to degradation of Axin and inactivation of GSK3 $\beta$ (glycogen synthase kinase $3 \beta$ ) and CKI $\alpha$ (casein kinase I $\alpha$ ), thereby inhibiting their interaction with other components of the destruction complex. As $\beta$-catenin accumulates in the cytoplasm, it translocates to the nucleus, where it forms a transcriptionally active complex with transcription factors of the T-cell factor (TCF)/lymphoid enhancer factor (LEF) family and coactivators, such as CBP (cyclic AMP response element-binding protein) and p300, driving the expression of Wnt target genes. Arrows indicate activation/induction; blunt ended lines indicate inhibition/blockade.

Abbreviation: APC, adenomtous polyposis coli.

associated with differentiation, cell polarity, and migration (Figure 2) and can be further dissected into the Wnt/planar cell polarity and $\mathrm{Wnt} /$ calcium pathways, although these two noncanonical pathways are likely to intersect. ${ }^{32,33}$ Pathways affected by the noncanonical pathway include calciumdependent and small GTPase-dependent signaling networks and the planar cell polarity signaling pathway, a pathway by which cells receive positional identity. Noncanonical signaling can be initiated by Wnt/frizzled receptor interactions without the help of $\operatorname{Lrp} 5 / 6,{ }^{34}$ or alternatively, receptor tyrosine kinase (RYK) and receptor tyrosine kinase-like orphan receptor (ROR) receptor tyrosine kinases can also act as Wnt receptors to activate $\beta$-catenin-independent signaling. ${ }^{35} \beta$-catenin-independent signaling also regulates small GTPases, such as RHOA (Ras homolog gene family member A), RAC (Ras-related $\mathrm{C} 3$ botulinum toxin substrate) and Cdc42 (cell division control protein 42), in a dishevelled (Dsh)-dependent manner. ${ }^{36}$ Noncanonical Wnt activated calcium flux results in the activation of various kinase cascades, including protein kinase $\mathrm{C}$, calcium/calmodulindependent protein kinase II, and JUN N-terminal kinase, which can activate NFAT (nuclear factor of activated T-cell) and AP-1-dependent transcription. Although dissection of the pathway into canonical and noncanonical may be convenient for discussion purposes, the reality is that these are interacting/intersecting pathways that can coordinately regulate and orchestrate complex processes during embryonic development, stem cell maintenance, tissue homeostasis, and wound healing. Wnt signaling plays critical roles in adults in the continuous processes of tissue homeostasis and regeneration of the hair and skin, ${ }^{37}$ maintenance of intestinal homeostasis, ${ }^{38}$ and hematopoiesis. ${ }^{39,40}$ Furthermore Wnt $/ \beta$ catenin signaling is involved in liver and lung repair after injury $^{41-43}$ and adult neurogenesis. ${ }^{44}$

\section{The role of Wnt signaling in stem cells}

The Wnt signaling pathway has emerged as a pivotal player in the specification and maintenance of stem cell lineages and has been shown to have an important role in multiple stem cell compartments in a wide array of tissues and organs. ${ }^{45-50}$ The small intestine is organized into villi (apical) and crypts (basal). Intestinal stem cells reside in intestinal crypts ${ }^{45}$ and their maintenance and proliferation 


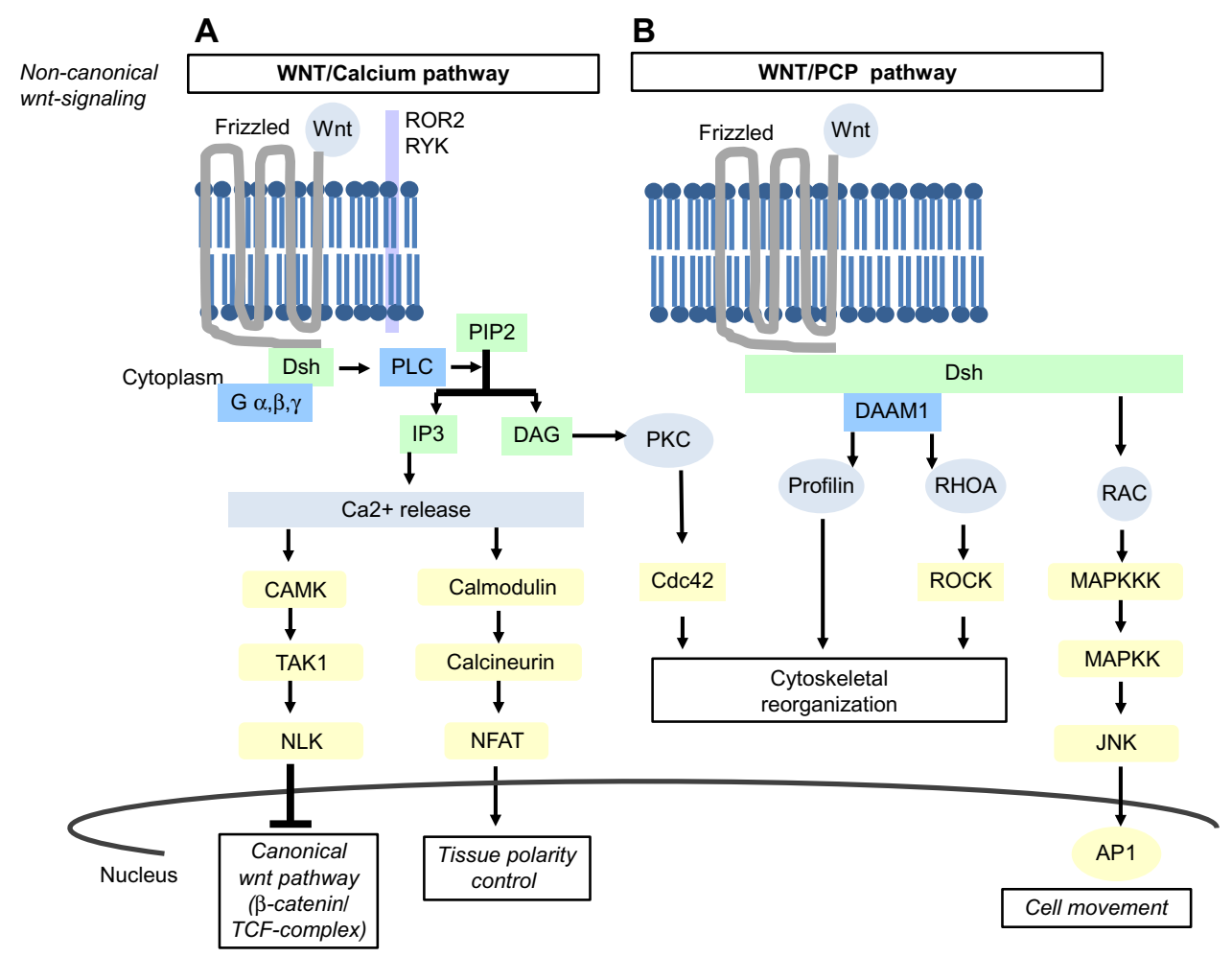

Figure 2 Noncanonical Wnt signaling.

Notes: (A) Noncanonical Wnt/calcium pathway. Wnt ligand binding to frizzled receptors activates Dsh and trimeric G-proteins (G $\alpha, \beta, \gamma)$, leading to the generation of IP3 (inositol I,4,5-triphosphate) and DAG2 (diacylglycerol) by PLC (phospholipase C)-mediated conversion of PIP2 (phosphatidylinositol biphosphate) and triggering release of calcium ions $\left(\mathrm{Ca}^{2+}\right)$. Subsequent calcium release activates CAMKII (calcium/calmodulin-dependent kinase II), TAK-I (TGF- $\beta$ activated kinase I) and NLK (nemo-like kinase). Calcium release also activates PKC (protein kinase C) and Cdc42 (cell division control protein 42), and, thereafter, actin cytoskeleton is rearranged. In addition, calcium release results in activation of calmodulin, calcineurin, and NFAT (nuclear factor of activated T-cell), which is critical for control of tissue polarity. Arrows indicate activation, blunt ended lines indicate inhibition/blockade. (B) Noncanonical Wnt/PCP (planar cell polarity) pathway. Wnt ligand binding to frizzled receptors leads to activation of dishevelled (Dsh), triggering stimulation of GTPases RAC (Ras-related C3 botulinum toxin substrate), Profilin and RHOA (Ras homolog gene family member A) through activation of DAAMI (dishevelled associated activator of morphogenesis I). Subsequently, actin cytoskeleton is rearranged. In addition, Dsh activates RAC and finally activates JNK (c-Jun-N-terminal-kinase) and API, which has been implicated in cell migration.

Abbreviations: RYK, receptor tyrosine kinase; ROR, receptor tyrosine kinase-like orphan receptor; ROCK, Rho-associated protein kinase; MAPKKK, mitogen-activated protein kinases; MAPKK, mitogen-activated protein kinases and API, activator protein I.

is Wnt dependent. ${ }^{51}$ The loss of positive Wnt regulators, such as TCF4 or $\beta$-catenin, as well as the overexpression of negative Wnt regulators, such as Dickkopf1, dramatically decreases the proliferation capacity of this stem cell compartment. ${ }^{52,53}$ Two distinct intestinal stem cell populations have been described. The first population is made up of +4 label retaining cells, ${ }^{54}$ which are highly quiescent and are activated apparently only after injury. ${ }^{54}$ This population is characterized by the stem cell marker Bmi1. ${ }^{55} \mathrm{~A}$ second population is made up of the crypt basal columnar cells (CBCs), which are interspersed between Paneth cells and express the surface marker $\operatorname{Lrg} 5 .^{55,56} \mathrm{CBC}$ s continuously cycle and are responsible for sustained tissue homeostasis. Lgr5 is a Wnt/ $\beta$-catenin target gene, which can amplify Wnt signaling in CBCs via its R-spondin ligand. ${ }^{57}$ Paneth cells, are an important source for Wnt ligands (ie, Wnt3, 6, 9b), ${ }^{58}$ which appear crucial for the maintenance of intestinal stem cells. ${ }^{59}$ Supporting this notion is the fact that depletion of
Paneth cells leads to a decrease in the number of intestinal stem cells. ${ }^{59}$ Wnt signaling is also critical for expression of the gene Sox9, which is important for Paneth cell lineage commitment. ${ }^{60,61}$

In the hematopoietic system, Wnt3a has been implicated in self-renewal and proliferation. ${ }^{49,62}$ Regulation of hematopoietic stem/progenitors, as well as lineage commitment of progenitors during hematopoiesis is highly Wnt dependent. ${ }^{39,40}$ Expression of survivin, a member of the inhibitor of apoptosis protein family, is important during hematopoeisis and is prominently upregulated in $\mathrm{CD} 4^{+}$hematopoietic stem/progenitor cells upon growth factor treatment. ${ }^{63}$ Inducible deletion of survivin leads to loss of hematopoietic progenitors and bone marrow ablation, whereas heterozygous deletion of survivin leads to defects in erythropoiesis. ${ }^{63,64}$ We previously demonstrated that survivin is a Wnt/ $\beta$-catenin/CBP dependent target gene in a variety of cancer cell types. ${ }^{65}$ More recently, we also 


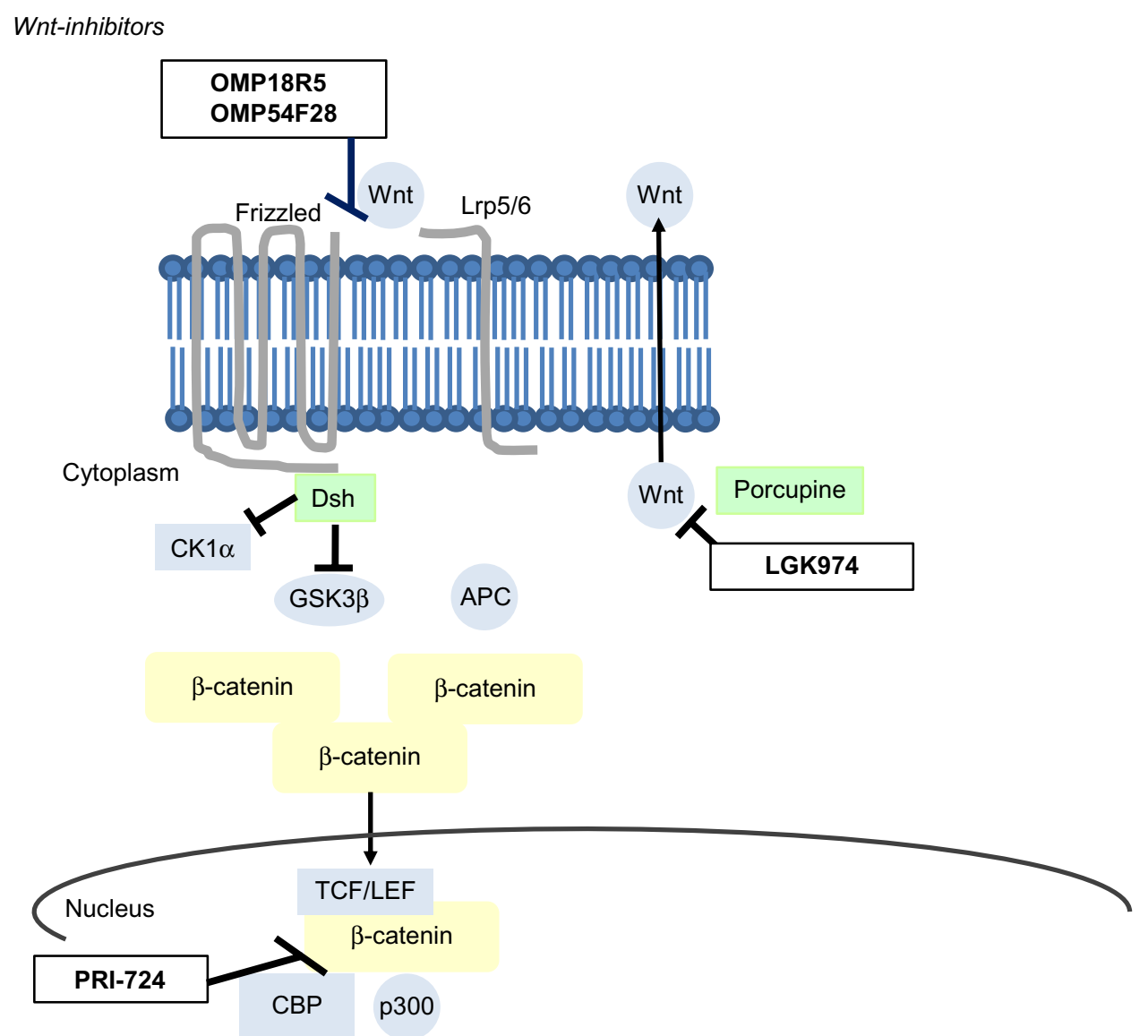

Figure 3 Schematic of Wnt inhibitors currently in clinical trials.

Notes: LGK974 is a porcupine inhibitor that inhibits Wnt posttranslational acylation. OMP-I8R5 is a fully humanized monoclonal antibody that binds to multiple frizzled (Fzd) receptors. OMP-54F28, is an Fc fusion protein with Fzd8, which binds all Wnt ligands. PRI-724 binds specifically to the coactivator CBP blocking its interaction with $\beta$-catenin. Arrows indicate activation/induction, blunt ended lines indicate inhibition/blockade.

Abbreviations: Dsh, dishevelled; CKI $\alpha$, casein kinase I $\alpha$; GSK3 $\beta$, glycogen synthase kinase 3 $\beta$; APC, adenomatous polyposis coli; TCF/LEF, T-cell factor/lymphoid enhancer factor; CBP, cyclic AMP response element-binding protein.

demonstrated that survivin is critical in drug resistance in leukemia. ${ }^{66}$ We have demonstrated that inhibition of the Wnt pathway by disrupting the $\mathrm{CBP} / \beta$-catenin interaction in pre-B acute lymphoblastic leukemia (ALL) represents a powerful mechanism to eradicate drug resistant subclones, which was associated with downregulation of survivin. ${ }^{67}$

Wnt signaling has also been implicated in mammary gland development and cell transformation. ${ }^{6-71}$ Ectopic expression of $\Delta \mathrm{N} \beta$-catenin ${ }^{72}$ or $W n t 1^{73}$ leads to ductal hyperplasia, while loss of function in $\beta$-catenin (using a dominant negative variant) has been shown to exert a negative effect on breast tissue development during pregnancy, in particular, lobuloalveolar proliferation. ${ }^{74}$ Overexpression of inhibitors (such as $\operatorname{Axin}^{75}$ ) or loss of lymphoid enhancer factor 1 function inhibits mammary differentiation of precursor cells. ${ }^{76}$ The bilayered mammary epithelium consists of luminal cells $(\mathrm{Ck} 8+, \mathrm{Muc1+})$ and basal cells $(\mathrm{Ck} 5+, \mathrm{p} 63+)$. Of these two cell types, the basal cells have been shown to express both Lrp5 and $6,{ }^{77}$ obligate canonical Wnt signaling receptors. ${ }^{78}$
Ductal mammary stem cells comprise a sub-population of basal epithelial cells and are capable of regenerating cleared mammary fat pads. ${ }^{79}$ Knockout studies for Lrp5 ${ }^{80}$ and loss of function mutations for the Lrp6 receptor ${ }^{50}$ showed significantly reduced activity in this cell compartment and impaired gland branching, suggesting impaired stem cell function. Wnt signaling has also been implicated in neuronal development and neuronal stem cell cells. ${ }^{48}$

\section{The role of Wnt signaling in cancer stem cells}

Considering the importance of the Wnt pathway in stem cell biology, it is not surprising that aberrant Wnt signaling has been implicated in the tumorigenic potential of stem cells. A typical approach to prospectively identify putative cancer stem cells is via cell surface markers $;{ }^{81}$ however, these are also expressed on normal somatic stem cells. Many of these markers are in fact direct Wnt target genes (including LGR5/GPR49, $,{ }^{56} \mathrm{CD} 44,{ }^{82} \mathrm{CD} 24,{ }^{83} \mathrm{CD} 133,{ }^{84} \mathrm{ABC}$ 
cassette genes, ${ }^{85,86}$ and EpCAM. ${ }^{87,88}$ ) The first report for the existence of CSCs in solid tumors emerged from studies in breast cancer by Al Hajj et al, ${ }^{23}$ who showed that cells that are $\mathrm{CD} 44^{\text {high }} \mathrm{CD} 24^{\text {low }}$ possess tumor initiating capacity. It has long been known that misexpression of Wnt ligands induces mammary adenocarcinomas. ${ }^{89}$ A role for the Wnt signaling pathway in glioblastoma stem cells has also recently been described. ${ }^{90}$ Another hallmark of aggressive breast cancers is an enrichment in an epithelial-mesenchymal transition (EMT)-like gene expression signature. ${ }^{91,92}$ For example, $W n t 1$ has been shown to upregulate Twist, ${ }^{3}$ thereby favoring EMTlike processes in breast cancer cells. ${ }^{94}$ Loss of E-Cadherin associated $\beta$-catenin in breast cancer cells leads to disruption in cell polarity resulting in an epithelial-mesenchymal transition, a CSC-like phenotype with a significant increase in the CD44high, CD24low population and increased Wnt signaling. ${ }^{95}$ The process of EMT has also been associated with activated $\beta$-catenin signaling. ${ }^{92,96}$ Conacci-Sorrell et al ${ }^{97}$ showed that slug, a strong inducer of EMT in tumors, induces nuclear accumulation of transcriptionally active $\beta$-catenin. Overexpression of the EMT inducing factors twist and snail (both putative Wnt target genes) increases the expression of CSCs markers. ${ }^{98}$ A connection between enhanced nuclear $\beta$-catenin signaling and EMT is consistent with the large number of $\beta$-catenin target genes (eg, S100A4, fibronectin, $L 1 C A M, C D 44, M M P 7$, and $u P A R$ ) whose expression is associated with invasion, migration, and metastasis. ${ }^{99}$ The cell surface protein CD133, is expressed by normal progenitor cells of the neural, hematopoietic, epithelial, and endothelial cell lineages. ${ }^{100-103}$ Recently, enrichment of CD133+ cells in colorectal cancer samples has been shown to enrich for a population of CSCs/TICs. ${ }^{26,100,104}$ These cells also express high levels of nuclear $\beta$-catenin. Furthermore, Lrg5/GPR49 is overexpressed in the majority of colorectal tumors compared with normal control tissue. ${ }^{105}$ Several studies have revealed that MDR-1, ABCG2, ABCA3, and $\mathrm{BRCP} 1$ are expressed in stem/progenitor cells from multiple adult tissues and that they contribute to the side population phenotype of stem cells. ${ }^{106}$ The expression of these so called multidrug resistance genes has been shown to also be associated with cancer stem cells and partially responsible for poor therapeutic responses. ${ }^{11,107} \mathrm{Wnt} / \beta$-catenin signaling appears to play an important role in ABCB1/MDR-1 transcription. Multiple putative TCF binding elements were identified in the ABCB1 promoter (-1813 to $-275 \mathrm{bp}) .{ }^{85}$ The side population assay has been utilized to identify rare drug resistant hematopoietic CSCs/TIC populations. ${ }^{108}$ Hematopoietic $\mathrm{CSCs} / \mathrm{TIC}$ populations have been shown to be Wnt/ $\beta$-catenin dependent. ${ }^{109,110}$ Furthermore, many Wnt signaling genes are upregulated in hematopoietic malignancies ${ }^{111}$ and epigenetic silencing of negative regulators of the Wnt signaling cascade is frequently associated with leukemias, including chronic myeloid leukemia. ${ }^{12,113}$

\section{Wnt signaling pathway as a potential oncotarget}

Aberrant regulation of Wnt signaling has emerged as a recurrent theme in cancer biology. ${ }^{114,115}$ The discovery in 1991 that mutations in the tumor suppressor adenomatous polyposis coli $(A P C)^{116,117}$ were associated with the vast majority of sporadic colorectal cancers via aberrant activation of Wnt signaling provided significant impetus to attempt to therapeutically target this pathway. Germline defects in APC are the cause of familial adenomatous polyposis. Affected individuals develop hundreds of polyps in the large intestine at an early age and ultimately progress to colorectal cancer with $100 \%$ penetrance. ${ }^{118}$ Loss of function in both alleles of APC is required for tumorigenesis and is connected to the protein's ability to regulate $\beta$-catenin protein stability, ${ }^{119}$ as well as chromosomal stability. ${ }^{120}$ APC is the most frequently mutated gene in human cancers. ${ }^{121,122} \mathrm{Wnt}$ pathway mutations are, however, not limited to colon cancer. Loss-of-function mutations in Axin have been found in hepatocellular carcinomas. Moreover, oncogenic $\beta$-catenin mutations, first described in colon cancer and melanoma, ${ }^{123}$ have also been found to occur in a wide variety of solid tumors, ${ }^{124}$ including hepatocellular carcinomas, ${ }^{125}$ thyroid tumors, ${ }^{126}$ and ovarian endometrioid adenocarcinomas. ${ }^{127}$ Additionally, epigenetic silencing is frequently observed to alter levels of expression of Wnt/ $\beta$-catenin pathway negative regulators. For example, methylation of genes that encode extracellular Wnt antagonists, such as secreted frizzledrelated proteins, has been described in colon, breast, prostate, lung, and other cancers. ${ }^{128-132}$ Increased expression of Wnt ligands ${ }^{133-135}$ or effector proteins (eg, Dsh) has also been reported. ${ }^{136-138}$ Clearly, the ability to target the Wnt signaling pathway offers enormous promise as an oncological target. However, significant risks and concerns regarding targeting such a critical pathway in normal stem cell maintenance and tissue homeostasis are ever present.

\section{Current Wnt inhibiting molecules: small molecules and biologics}

Despite a wealth of information and significant investment in research and development, only recently have a few therapeutic agents that specifically target the Wnt pathway been 
Table I Clinically approved nonspecific Wnt antagonist

\begin{tabular}{llll}
\hline $\begin{array}{l}\text { Clinical } \\
\text { antogonist }\end{array}$ & Disease & Mechanism & Reference \\
\hline $\begin{array}{l}\text { NSAID } \\
\text { (aspirin, }\end{array}$ & PGE2 generated & I39-146 \\
sulindac, & & $\begin{array}{l}\text { via COX suppresses } \\
\text { celecoxib) }\end{array}$ & \\
Retinoids & APML & Unclear & 147 \\
Vitamin D & $\begin{array}{l}\text { Colorectal cancer, } \\
\text { breast cancer }\end{array}$ & Unclear & 148 \\
\hline
\end{tabular}

Abbreviations: NSAID, nonsteroidal anti-inflammatory drug; PGE2, prostaglandin E2; COX, cyclooxygenase; APML, acute promyelocytic leukemia.

introduced into clinical trials (Table 1). Several US Food and Drug Administration (FDA)-approved drugs affect Wnt signaling, albeit nonspecifically. For example, nonsteroidal anti-inflammatory drugs, including aspirin and sulindac, as well as the selective COX-2 inhibitor celecoxib, inhibit the activity of cyclooxygenase, a key enzyme in the arachidonic acid cascade. Prostaglandin E2 generated via cyclooxygenase suppresses $\beta$-catenin degradation and thereby enhances Wnt/ $\beta$-catenin signaling. ${ }^{139-143}$ Nonsteroidal anti-inflammatory drugs demonstrated the ability to reduce polyp formation in familial adenomatous polyposis, in which autosomal dominant mutations in the APC gene lead to activation of $\mathrm{Wnt} / \beta$-catenin signaling. ${ }^{144-146}$ Vitamins, in particular retinoids, which are synthesized from vitamin A in the body, are used in some forms of cancer therapy (most notably acute promyeloctyic leukemia) and also chemoprevention. The active form of vitamin $\mathrm{D}, 1 \alpha, 25$-dihydroxyvitamin $\mathrm{D} 3$, and its synthetic derivatives have demonstrated chemopreventive effects in animal models of colorectal and breast cancers. Although the exact mechanism by which vitamins inhibit the $\mathrm{Wnt} / \beta$-catenin signaling pathway is not fully elaborated, it has been suggested that activated nuclear receptors for vitamins compete for binding to the transcriptional coactivators $\mathrm{CBP} /$ p300 with $\beta$-catenin/TCF. ${ }^{147,148}$

Polyphenols are a group of chemicals found in plants, characterized by the presence of more than one phenol unit per molecule. Several polyphenols, including quercetin, epigallocatechin-3-gallate, curcumin, and resveratrol have been implicated as nonspecific inhibitors of the Wnt/ $\beta$-catenin signaling pathway, although the mechanisms of action of these agents are not clear. ${ }^{149-153}$ Through screening a library of FDA-approved drugs, the antihelminthic agent pyrvinium was identified. This agent was shown to potentiate the activity of the casein kinase 1 alpha leading to enhanced degradation of $\beta$-catenin and the coactivator Pygo and thereby reduction of $\mathrm{Wnt} / \beta$-catenin signaling. ${ }^{154}$

A number of molecularly targeted agents have been reported, which can be classified basically into several classes, ie, $\beta$-catenin/TCF-antagonists, PDZ (postsynaptic density protein 95 , Drosophila disc large tumor suppressor, zonula occludens-1 protein) ${ }^{155}$ the domain of Dsh binders, and other mechanism-based inhibitors, principally enzymes (eg, kinases, tankyrases, ${ }^{156}$ Porcupine, ${ }^{157}$ and biologics). To date, most of these have only been evaluated preclinically and for several recent reviews the reader is referred to the following. ${ }^{6,114,158,159}$ Ongoing clinical trials of Wnt inhibitors/modulators are summarized in Table 2 and Figure 3. Recently, Novartis International AG, (Basel, Switzerland) initiated a Phase I trial of the Porcupine inhibitor LGK974 (NCT01351103) ${ }^{160}$ to treat a variety of malignancies (melanoma, breast cancer, and pancreatic adenocarcinoma) associated with aberrant Wnt signaling. Porcupine is a member of a family of O-acyltransferases that is apparently dedicated to Wnt posttranslational acylation. ${ }^{161}$ This trial has not been completed and to date no public information is available.

Two Wnt-targeting biologics developed by OncoMed Pharmaceuticals, Redwood City, CA, USA have recently entered clinical trials. OMP-18R5 is a fully humanized monoclonal antibody that binds to multiple frizzled receptors. ${ }^{162}$ An open label Phase Ia study for solid tumors was recently completed (NCT01345201). The results of this trial were recently reported at the American Society of Clinical Oncology conference in June 2013. ${ }^{163} \mathrm{~A}$ total of 18 patients were treated in 5 dose escalation cohorts $(0.5$ and $1 \mathrm{mg} / \mathrm{kg}$ once per week; $0.5 \mathrm{mg} / \mathrm{kg}$ every two weeks; 1 and $2.5 \mathrm{mg} / \mathrm{kg}$ every three weeks). The most common related adverse events included grade 1 and 2 fatigue, vomiting, abdominal pain,

Table 2 Clinical trials of Wnt inhibitors/modulators

\begin{tabular}{lll}
\hline Clinical trials & Disease & Mechanism \\
\hline OMPI8R5, Vantictumab & Solid tumors & Humanized Ab against multiple Fzd receptors \\
OMP-54F28, Fzd8-Fc & Pancreatic, ovarian, hepatocellular, colorectal, & Fc fusion protein with Fzd8, which binds all \\
& and breast & Wnt ligands \\
PRI-724 & Solid tumors, colon and pancreatic cancer, CML, & Small molecule inihibitor of CBP/catenin binding I67 \\
& and AML & \\
LGK974, Porcupine inhibitor & Melanoma, breast, and pancreatic adenocarcinoma & Wnt posttranslational acylation \\
\hline
\end{tabular}

Abbreviations: Ab, antibody; Fzd, frizzled; CML, chronic myeloid leukemia; CBP, CREB-binding protein; AML, acute myeloid leukemia. 
constipation, diarrhea, and nausea. The only related grades greater than or equal to 3 were dose limiting toxicities of grade 3 diarrhea and vomiting in one patient at $1 \mathrm{mg} / \mathrm{kg} / \mathrm{per}$ week. 1 patient at $0.5 \mathrm{mg} / \mathrm{kg}$ per week suffered a therapyrelated bone fracture on day 110 . Further clinical trials using OMP-18R5 in combination with other agents in solid tumors (NCT01957007) and breast cancer (NCT01973309) are ongoing. The second agent, OMP-54F28, is an Fc fusion protein with frizzled family receptor 8 , which binds all Wnt ligands. A trial in solid tumors was initiated last year (NCT01608867) with the primary end point being safety. ${ }^{164}$ Potential deleterious effects of this agent on bone formation/turnover have been prospectively designed into the trial. Subjects will be monitored throughout the study for effects on bone density and turnover. Dose escalation studies in combination with other agents are currently ongoing in hepatocellular cancer, liver cancer (NCT02069145), ovarian cancer (NCT02092363), and pancreatic cancer (NCT02050178).

Our group used a Topflash reporter gene screen to identify inhibitors of Wnt signaling in SW480 colon carcinoma cells. This led to the identification of ICG-001 from a library of secondary structure mimetics. ${ }^{165}$ In this assay, ICG-001 had an IC50 value of $3 \mu \mathrm{M}$. We subsequently identified and validated, using a gain-of-function/loss-of-function strategy, that ICG-001 binds specifically and with high affinity $(\sim 1 \mathrm{nM})$ to the coactivator CBP, but importantly, not to its closely related homolog p300, despite the fact that these two coactivators are up to $93 \%$ identical, with even higher homology, at the amino acid level. ${ }^{165,166}$ PRI-724, a second generation specific $\mathrm{CBP} /$ catenin antagonist, developed by Prism Pharma Co., Ltd. Yokohama, Japan entered an open label Phase Ia safety study in subjects with solid tumors, where the expression of the biomarker survivin/BIRC5 was measured by immuno-magnetic RT-PCR in circulating tumor cells. Trial results were reported at the American Society of Clinical Oncology conference in June 2013 (NCT01302405): ${ }^{167}$ Eighteen patients were treated (dose escalation from $40-1,280 \mathrm{mg} / \mathrm{m}^{2} /$ day) via continuous infusion for 7 days. PRI-724 had a low toxicity profile: one dose limiting toxicity of grade 3 hyperbilirubinemia was reported. Reported grade 2 adverse events were diarrhea (2 patients, 11\%), bilirubin elevation ( 2 patients, 11\%), hypophosphatemia (2 patients, $11 \%$ ); nausea (1 patient, $6 \%$ ), fatigue (1 patient, $6 \%$ ), anorexia (1 patient, $6 \%$ ), thrombocytopenia ( 1 patient, $6 \%$ ), and alkaline phosphatase elevation ( 1 patient, $6 \%$ ). There was no maximum tolerated dose at the doses tested. Three patients with colon cancer had stable disease for 8,10 , and 12 weeks. Down regulation of survivin/BIRC5 in circulating tumor cells was dose dependent. ${ }^{167}$ Additional trials with PRI-724 in myeloid malignancies (NCT01606579) and in combination with gemcitabine in pancreatic adenocarcinoma (NCT01764477) are ongoing.

\section{Development of novel Wnt inhibitors: challenges and prospects}

More than 30 years after the groundbreaking discovery of Wnt signaling and extensive investigation into this fundamental and highly evolutionarily conserved pathway, there is still no FDA approved agent that specifically targets aberrant Wnt signaling in cancer. Very recently, a number of small molecules and biologics have entered human clinical trials. Despite exciting preclinical data in a variety of tumor models, it is still too early to know if any of these therapeutic agents will be efficacious with an acceptable safety profile. However, it is already clear that successfully targeting Wnt signaling in cancer will require a fine balancing act, whereby the "dark side" of Wnt signaling in cancer can be abrogated without interfering with the critical role of Wnt signaling in tissue homeostasis (eg, intestinal epithelium, blood, and bone) and repair. Numerous potential concerns arise in the development of therapeutic strategies that antagonize the Wnt pathway. Therapeutic agents that target critical developmental signal transduction pathways (eg, Wnt) are likely to have devastating effects on embryonic patterning. Further concerns about on-target toxicity include effects on intestinal stem cells, bone turnover, and hematopoiesis. For example, the Porcupine inhibitor LGK974 exhibited 63\% tumor growth delay when administered at $3 \mathrm{mg} / \mathrm{kg} /$ day. ${ }^{168}$ However, at a dose of $20 \mathrm{mg} / \mathrm{kg} / \mathrm{day}$, significant loss of intestinal epithelium was observed. Concerns about potential deleterious effects on bone formation/turnover have been prospectively addressed in the OMP-54F28 trial design (NCT01608867), as all subjects receive 30 days of vitamin D3 and calcium carbonate after discontinuation of OMP-54F28 and are monitored during the study for effects on bone density and turnover. It remains to be seen if toxic side effects occur with inhibitors of Wnt signaling, and, if there are none, it would be critical to understand why.

Despite all of these potential concerns regarding targeting Wnt signaling in cancer, there is also tremendous excitement as our knowledge of this pathway continues to increase and our clinical experience with novel Wnt-targeting therapeutic agents expands. 


\section{Acknowledgments}

YMK was supported by Hyundai Hope on Wheels, V-Foundation, St Baldrick's Scholar Award, and NIH R01CA172896 (YMK). MK is supported by USC Norris Comprehensive Cancer Center Support Grant P30 CA014089, NIH R01CA166161, R21NS074392, R21AI105057 and NIH R01 HL112638. We apologize for the omission of any of our colleague's work due to space limitations.

\section{Disclosure}

MK owns stock in and is a consultant for Prism Pharma Co., Ltd., Yokohama, Japan. YMK declares no conflict of interest.

\section{References}

1. Reya T, Morrison SJ, Clarke MF, Weissman IL. Stem cells, cancer, and cancer stem cells. Nature. 2001;414:105-111.

2. Gage FH, Temple S. Neural stem cells: generating and regenerating the brain. Neuron. 2013;80:588-601.

3. Cullen SM, Mayle A, Rossi L, Goodell MA. Hematopoietic stem cell development: an epigenetic journey. Curr Top Dev Biol. 2014;107: 39-75.

4. Clevers H. The intestinal crypt, a prototype stem cell compartment. Cell. 2013;154:274-284.

5. Miki T, Yasuda SY, Kahn M. Wnt/beta-catenin signaling in embryonic stem cell self-renewal and somatic cell reprogramming. Stem Cell Rev. 2011;7:836-846.

6. Takahashi-Yanaga F, Kahn M. Targeting Wnt signaling: can we safely eradicate cancer stem cells? Clin Cancer Res. 2010;16: 3153-3162.

7. Merchant AA, Matsui W. Targeting Hedgehog - a cancer stem cell pathway. Clin Cancer Res. 2010;16:3130-3140.

8. Liu J, Sato C, Cerletti M, Wagers A. Notch signaling in the regulation of stem cell self-renewal and differentiation. Curr Top Dev Biol. 2010;92:367-409.

9. Cohnheim J. Ueber entzuendung und eiterung [About inflammation and suppuration]. Path Anat Physiol Klin Med. 1867;40:1-79.

10. Visvader JE, Lindeman GJ. Cancer stem cells in solid tumours: accumulating evidence and unresolved questions. Nat Rev Cancer. 2008;8:755-768

11. O'Brien CA, Kreso A, Jamieson CH. Cancer stem cells and self-renewal. Clin Cancer Res. 2010;16:3113-3120.

12. Armanios M, Greider CW. Telomerase and cancer stem cells. Cold Spring Harb Symp Quant Biol. 2005;70:205-208.

13. Clevers H. The cancer stem cell: premises, promises and challenges. Nat Med. 2011;17:313-319.

14. Visvader JE, Lindeman GJ. Stem cells and cancer - the promise and puzzles. Mol Oncol. 2010;4:369-372.

15. Hussenet T, Dembélé D, Martinet N, Vignaud JM, du Manoir MS. An adult tissue-specific stem cell molecular phenotype is activated in epithelial cancer stem cells and correlated to patient outcome. Cell Cycle. 2010;9:321-327.

16. D'Angelo RC, Wicha MS. Stem cells in normal development and cancer. Prog Mol Biol Transl Sci. 2010;95:113-158.

17. Kelly PN, Dakic A, Adams JM, Nutt SL, Strasser A. Tumor growth need not be driven by rare cancer stem cells. Science. 2007; (3175836):337.

18. Bruce WR, van der Gaag H. A quantitative assay for the number of murine lymphoma cells capable of proliferation in vivo. Nature. 1963;199:79-80.
19. Bonnet D, Dick JE. Human acute myeloid leukemia is organized as a hierarchy that originates from a primitive hematopoietic cell. Nat Med. 1997;3:730-737.

20. Jamieson CH, Weissman IL, Passegue E. Chronic versus acute myelogenous leukemia: a question of self-renewal. Cancer Cell. 2004;6: 531-533.

21. Singh SK, Hawkins C, Clarke ID, et al. Identification of human brain tumour initiating cells. Nature. 2004;432:396-401.

22. Fang D, Nguyen TK, Leishear K, et al. A tumorigenic subpopulation with stem cell properties in melanomas. Cancer Res. 2005;65: 9328-9337.

23. Al-Hajj M, Wicha MS, Benito-Hernandez A, Morrison SJ, Clarke MF. Prospective identification of tumorigenic breast cancer cells. Proc Natl Acad Sci U S A. 2003;100:3983-3988.

24. Ma S, Chan KW, Hu L, et al. Identification and characterization of tumorigenic liver cancer stem/progenitor cells. Gastroenterology. 2007; 132:2542-2556.

25. Li C, Heidt DG, Dalerba P, et al. Identification of pancreatic cancer stem cells. Cancer Res. 2007;67:1030-1037.

26. O'Brien CA, Pollett A, Gallinger S, Dick JE. A human colon cancer cell capable of initiating tumour growth in immunodeficient mice. Nature. 2007;445:106-110.

27. Akiyama T. Wnt/beta-catenin signaling. Cytokine Growth Factor Rev. 2000;11:273-282.

28. Niehrs C. The complex world of WNT receptor signalling. Nat Rev Mol Cell Biol. 2012;13:767-779.

29. Veeman MT, Axelrod JD, Moon RT. A second canon. Functions and mechanisms of beta-catenin-independent Wnt signaling. Dev Cell. 2003;5:367-377.

30. Mosimann C, Hausmann G, Basler K. Beta-catenin hits chromatin: regulation of Wnt target gene activation. Nat Rev Mol Cell Biol. 2009; 10:276-286.

31. Logan CY, Nusse R. The Wnt signaling pathway in development and disease. Annu Rev Cell Dev Biol. 2004;20:781-810.

32. Moon RT, Kohn AD, De Ferrari GV, Kaykas A. WNT and betacatenin signalling: diseases and therapies. Nat Rev Genet. 2004;5: 691-701.

33. Thrasivoulou C, Millar M, Ahmed A. Activation of intracellular calcium by multiple Wnt ligands and translocation of beta-catenin into the nucleus: a convergent model of $\mathrm{Wnt} / \mathrm{Ca} 2+$ and $\mathrm{Wnt} /$ beta-catenin pathways. J Biol Chem. 2013;288:35651-35659.

34. Yamamoto S, Nishimura O, Misaki K, et al. Cthrc1 selectively activates the planar cell polarity pathway of Wnt signaling by stabilizing the Wnt-receptor complex. Dev Cell. 2008;15:23-36.

35. Angers S, Moon RT. Proximal events in Wnt signal transduction. Nat Rev Mol Cell Biol. 2009;10:468-477.

36. Lai SL, Chien AJ, Moon RT. Wnt/Fz signaling and the cytoskeleton: potential roles in tumorigenesis. Cell Res. 2009;19:532-545.

37. Alonso L, Fuchs E. Stem cells in the skin: waste not, Wnt not. Genes Dev. 2003;17:1189-1200.

38. Pinto D, Clevers H. Wnt control of stem cells and differentiation in the intestinal epithelium. Exp Cell Res. 2005;306:357-363.

39. Nemeth MJ, Mak KK, Yang Y, Bodine DM. Beta-Catenin expression in the bone marrow microenvironment is required for long-term maintenance of primitive hematopoietic cells. Stem Cells. 2009;27: 1109-1119.

40. Malhotra S, Kincade PW. Wnt-related molecules and signaling pathway equilibrium in hematopoiesis. Cell Stem Cell. 2009;4:27-36.

41. Monga SP. Role of Wnt/beta-catenin signaling in liver metabolism and cancer. Int J Biochem Cell Biol. 2011;43:1021-1029.

42. Beers MF, Morrisey EE. The three R's of lung health and disease: repair, remodeling, and regeneration. J Clin Invest. 2011;121: 2065-2073.

43. Whyte JL, Smith AA, Helms JA. Wnt signaling and injury repair. Cold Spring Harb Perspect Biol. 2012;4:a008078.

44. Inestrosa NC, Arenas E. Emerging roles of Wnts in the adult nervous system. Nat Rev Neurosci. 2010;11:77-86. 
45. Cheng H, Leblond CP. Origin, differentiation and renewal of the four main epithelial cell types in the mouse small intestine. V. Unitarian Theory of the origin of the four epithelial cell types. Am JAnat. 1974;141: 537-561.

46. Lin SA, Barker N. Gastrointestinal stem cells in self-renewal and cancer. J Gastroenterol. 2011;46:1039-1055.

47. Anversa P, Leri A. Innate regeneration in the aging heart: healing from within. Mayo Clin Proc. 2013;88:871-883.

48. Williams A. Central nervous system regeneration - where are we? QJM. 2014;107(5):335-339.

49. Reya T, Duncan AW, Ailles L, et al. A role for Wnt signalling in selfrenewal of haematopoietic stem cells. Nature. 2003;423:409-414.

50. Lindvall C, Zylstra CR, Evans N, et al. The Wnt co-receptor Lrp6 is required for normal mouse mammary gland development. PLoS One. 2009;4:e5813.

51. Farin HF, van Es JH, Clevers H. Redundant sources of Wnt regulate intestinal stem cells and promote formation of Paneth cells. Gastroenterology. 2012;143:1518-1529.

52. Pinto D, Gregorieff A, Begthel H, Clevers H. Canonical Wnt signals are essential for homeostasis of the intestinal epithelium. Genes Dev. 2003;17:1709-1713.

53. Korinek V, Barker N, Moerer P, et al. Depletion of epithelial stem-cell compartments in the small intestine of mice lacking Tcf-4. Nat Genet. 1998;19:379-383.

54. Tian H, Biehs B, Warming S, et al. A reserve stem cell population in small intestine renders Lgr5-positive cells dispensable. Nature. 2011;478:255-259.

55. Yan KS, Chia LA, Li X, et al. The intestinal stem cell markers Bmil and Lgr5 identify two functionally distinct populations. Proc Natl Acad Sci U S A. 2012;109:466-471.

56. Barker N, van Es JH, Kuipers J, et al. Identification of stem cells in small intestine and colon by marker gene Lgr5. Nature. 2007;449: 1003-1007.

57. de Lau W, Barker N, Low TY, et al. Lgr5 homologues associate with Wnt receptors and mediate R-spondin signalling. Nature. 2011;476:293-297.

58. Gregorieff A, Pinto D, Begthel H, Destree O, Kielman M, Clevers H. Expression pattern of Wnt signaling components in the adult intestine. Gastroenterology. 2005;129:626-638.

59. Sato T, van Es JH, Snippert HJ, et al. Paneth cells constitute the niche for Lgr5 stem cells in intestinal crypts. Nature. 2011;469:415-418.

60. Bastide P, Darido C, Pannequin J, et al. Sox 9 regulates cell proliferation and is required for Paneth cell differentiation in the intestinal epithelium. J Cell Biol. 2007;178:635-648.

61. Mori-Akiyama Y, van den Born M, van Es JH, et al. SOX9 is required for the differentiation of paneth cells in the intestinal epithelium. Gastroenterology. 2007;133:539-546.

62. Willert K, Brown JD, Danenberg E, et al. Wnt proteins are lipidmodified and can act as stem cell growth factors. Nature. 2003;423: 448-452.

63. Fukuda S, Pelus LM. Regulation of the inhibitor-of-apoptosis family member survivin in normal cord blood and bone marrow CD34(+) cells by hematopoietic growth factors: implication of survivin expression in normal hematopoiesis. Blood. 2001;98:2091-2100.

64. Leung CG, Xu Y, Mularski B, Liu H, Gurbuxani S, Crispino JD. Requirements for survivin in terminal differentiation of erythroid cells and maintenance of hematopoietic stem and progenitor cells. J Exp Med. 2007;204:1603-1611.

65. Ma H, Nguyen C, Lee KS, Kahn M. Differential roles for the coactivators $\mathrm{CBP}$ and p300 on TCF/beta-catenin-mediated survivin gene expression. Oncogene. 2005;24:3619-3631.

66. Park E, Gang EJ, Hsieh YT, et al. Targeting survivin overcomes drug resistance in acute lymphoblastic leukemia. Blood. 2011;118: 2191-2199.

67. Gang EJ, Hsieh YT, Pham J, et al. Small-molecule inhibition of CBP/ catenin interactions eliminates drug-resistant clones in acute lymphoblastic leukemia. Oncogene. 2014;33(17):2169-2178.
68. Zeng YA, Nusse R. Wnt proteins are self-renewal factors for mammary stem cells and promote their long-term expansion in culture. Cell Stem Cell. 2010;6:568-577.

69. Klaus A, Birchmeier W. Wnt signalling and its impact on development and cancer. Nat Rev Cancer. 2008;8:387-398.

70. Turashvili G, Bouchal J, Burkadze G, Kolar Z. Wnt signaling pathway in mammary gland development and carcinogenesis. Pathobiology. 2006;73:213-223.

71. Boras-Granic K, Wysolmerski JJ. Wnt signaling in breast organogenesis. Organogenesis. 2008;4:116-122.

72. Imbert A, Eelkema R, Jordan S, Feiner H, Cowin P. Delta N89 betacatenin induces precocious development, differentiation, and neoplasia in mammary gland. $J$ Cell Biol. 2001;153:555-568.

73. Liu BY, McDermott SP, Khwaja SS, Alexander CM. The transforming activity of Wnt effectors correlates with their ability to induce the accumulation of mammary progenitor cells. Proc Natl Acad Sci US A. 2004;101:4158-4163.

74. Tepera SB, McCrea PD, Rosen JM. A beta-catenin survival signal is required for normal lobular development in the mammary gland. $J$ Cell Sci. 2003;116:1137-1149.

75. Hsu W, Shakya R, Costantini F. Impaired mammary gland and lymphoid development caused by inducible expression of Axin in transgenic mice. J Cell Biol. 2001;155:1055-1064.

76. Boras-Granic K, Chang H, Grosschedl R, Hamel PA. Lefl is required for the transition of Wnt signaling from mesenchymal to epithelial cells in the mouse embryonic mammary gland. Dev Biol. 2006;295: 219-231.

77. Alexander CM, Goel S, Fakhraldeen SA, Kim S. Wnt signaling in mammary glands: plastic cell fates and combinatorial signaling. Cold Spring Harb Perspect Biol. 2012;4(10):a008037.

78. Brennan KR, Brown AM. Wnt proteins in mammary development and cancer. J Mammary Gland Biol Neoplasia. 2004;9:119-131.

79. Kordon EC, Smith GH. An entire functional mammary gland may comprise the progeny from a single cell. Development. 1998;125: 1921-1930.

80. Badders NM, Goel S, Clark RJ, et al. The Wnt receptor, Lrp5, is expressed by mouse mammary stem cells and is required to maintain the basal lineage. PLoS One. 2009;4:e6594.

81. Klonisch T, Wiechec E, Hombach-Klonisch S, et al. Cancer stem cell markers in common cancers - therapeutic implications. Trends $\mathrm{Mol}$ Med. 2008; 14:450-460.

82. Wielenga VJ, Smits R, Korinek V, et al. Expression of CD44 in Apc and Tcf mutant mice implies regulation by the WNT pathway. Am J Pathol. 1999;154:515-523.

83. Shulewitz M, Soloviev I, Wu T, Koeppen H, Polakis P, Sakanaka C. Repressor roles for TCF-4 and Sfrp1 in Wnt signaling in breast cancer. Oncogene. 2006;25:4361-4369.

84. Katoh Y, Katoh M. Comparative genomics on PROM1 gene encoding stem cell marker CD133. Int J Mol Med. 2007;19:967-970.

85. Yamada T, Takaoka AS, Naishiro Y, et al. Transactivation of the multidrug resistance 1 gene by T-cell factor 4/beta-catenin complex in early colorectal carcinogenesis. Cancer Res. 2000;60:4761-4766.

86. Corrêa S, Binato R, Du Rocher B, Castelo-Branco MT, Pizzatti L, Abdelhay E. Wnt/beta-catenin pathway regulates ABCB1 transcription in chronic myeloid leukemia. BMC Cancer. 2012;12:303.

87. Munz M, Baeuerle PA, Gires O. The emerging role of EpCAM in cancer and stem cell signaling. Cancer Res. 2009;69:5627-5629.

88. Yamashita T, Budhu A, Forgues M, Wang XW. Activation of hepatic stem cell marker EpCAM by Wnt-beta-catenin signaling in hepatocellular carcinoma. Cancer Res. 2007;67:10831-10839.

89. Nusse R, Varmus HE. Many tumors induced by the mouse mammary tumor virus contain a provirus integrated in the same region of the host genome. Cell. 1982;31:99-109.

90. Sandberg CJ, Altschuler G, Jeong J, et al. Comparison of glioma stem cells to neural stem cells from the adult human brain identifies dysregulated Wnt-signaling and a fingerprint associated with clinical outcome. Exp Cell Res. 2013;319:2230-2243. 
91. Zhang Y, Toy KA, Kleer CG. Metaplastic breast carcinomas are enriched in markers of tumor-initiating cells and epithelial to mesenchymal transition. Mod Pathol. 2012;25:178-184.

92. DiMeo TA, Anderson K, Phadke P, et al. A novel lung metastasis signature links Wnt signaling with cancer cell self-renewal and epithelial-mesenchymal transition in basal-like breast cancer. Cancer Res. 2009;69:5364-5373.

93. Howe LR, Watanabe O, Leonard J, Brown AM. Twist is up-regulated in response to Wnt 1 and inhibits mouse mammary cell differentiation. Cancer Res. 2003;63:1906-1913.

94. Takebe N, Warren RQ, Ivy SP. Breast cancer growth and metastasis: interplay between cancer stem cells, embryonic signaling pathways and epithelial-to-mesenchymal transition. Breast Cancer Res. 2011;13:211.

95. Bhat-Nakshatri P, Appaiah H, Ballas C, et al. SLUG/SNAI2 and tumor necrosis factor generate breast cells with CD44+/CD24- phenotype. BMC Cancer. 2010;10:411.

96. Moreno-Bueno G, Portillo F, Cano A. Transcriptional regulation of cell polarity in EMT and cancer. Oncogene. 2008;27:6958-6969.

97. Conacci-Sorrell M, Simcha I, Ben-Yedidia T, Blechman J, Savagner P, Ben-Ze'ev A. Autoregulation of E-cadherin expression by cadherincadherin interactions: the roles of beta-catenin signaling, Slug, and MAPK. J Cell Biol. 2003;163:847-857.

98. Mani SA, Guo W, Liao MJ, et al. The epithelial-mesenchymal transition generates cells with properties of stem cells. Cell. 2008;133: 704-715.

99. Brabletz T, Hlubek F, Spaderna S, et al. Invasion and metastasis in colorectal cancer: epithelial-mesenchymal transition, mesenchymalepithelial transition, stem cells and beta-catenin. Cells Tissues Organs. 2005;179:56-65.

100. Wang J, O’Bara MA, Pol SU, Sim FJ. CD133/CD140a-based isolation of distinct human multipotent neural progenitor cells and oligodendrocyte progenitor cells. Stem Cells Dev. 2013;22:2121-2131.

101. Shmelkov SV, St Clair R, Lyden D, Rafii S. AC133/CD133/Prominin-1. Int J Biochem Cell Biol. 2005;37:715-719.

102. Corbeil D, Marzesco AM, Wilsch-Brauninger M, Huttner WB. The intriguing links between prominin-1 (CD133), cholesterol-based membrane microdomains, remodeling of apical plasma membrane protrusions, extracellular membrane particles, and (neuro)epithelial cell differentiation. FEBS Lett. 2010;584:1659-1664.

103. Yin AH, Miraglia S, Zanjani ED, et al. AC133, a novel marker for human hematopoietic stem and progenitor cells. Blood. 1997;90: 5002-5012.

104. Vermeulen L, Todaro M, de Sousa Mello F, et al. Single-cell cloning of colon cancer stem cells reveals a multi-lineage differentiation capacity Proc Natl Acad Sci U S A. 2008;105:13427-13432.

105. Uchida H, Yamazaki K, Fukuma M, et al. Overexpression of leucinerich repeat-containing $\mathrm{G}$ protein-coupled receptor 5 in colorectal cancer. Cancer Sci. 2010;101:1731-1737.

106. Haraguchi N, Utsunomiya T, Inoue H, et al. Characterization of a side population of cancer cells from human gastrointestinal system. Stem Cells. 2006;24:506-513.

107. Hirschmann-Jax C, Foster AE, Wulf GG, Goodell MA, Brenner MK. A distinct "side population" of cells in human tumor cells: implications for tumor biology and therapy. Cell Cycle. 2005;4:203-205.

108. Moshaver B, van Rhenen A, Kelder A, et al. Identification of a small subpopulation of candidate leukemia-initiating cells in the side population of patients with acute myeloid leukemia. Stem Cells. 2008;26:3059-3067.

109. Wang Y, Krivtsov AV, Sinha AU, et al. The Wnt/beta-catenin pathway is required for the development of leukemia stem cells in AML. Science. 2010;327:1650-1653.

110. Heidel FH, Bullinger L, Feng Z, et al. Genetic and pharmacologic inhibition of beta-catenin targets imatinib-resistant leukemia stem cells in CML. Cell Stem Cell. 2012;10:412-424.

111. Radich JP, Dai H, Mao M, et al. Gene expression changes associated with progression and response in chronic myeloid leukemia. Proc Natl Acad Sci U S A. 2006;103:2794-2799.
112. Pehlivan M, Sercan Z, Sercan HO. sFRP1 promoter methylation is associated with persistent Philadelphia chromosome in chronic myeloid leukemia. Leuk Res. 2009;33:1062-1067.

113. Holland JD, Klaus A, Garratt AN, Birchmeier W. Wnt signaling in stem and cancer stem cells. Curr Opin Cell Biol. 2013;25:254-264.

114. Polakis P. Drugging Wnt signalling in cancer. EMBO J. 2012;31: 2737-2746.

115. Anastas JN, Moon RT. WNT signalling pathways as therapeutic targets in cancer. Nat Rev Cancer. 2013;13:11-26.

116. Groden J, Thliveris A, Samowitz W, et al. Identification and characterization of the familial adenomatous polyposis coli gene. Cell. 1991;66:589-600.

117. Kinzler KW, Nilbert MC, Su LK, et al. Identification of FAP locus genes from chromosome 5q21. Science. 1991;253:661-665.

118. Bodmer WF. Cancer genetics: colorectal cancer as a model. J Hum Genet. 2006;51:391-396.

119. Polakis P. The many ways of Wnt in cancer. Curr Opin Genet Dev. 2007; 17:45-51.

120. Lengauer C, Kinzler KW, Vogelstein B. Genetic instabilities in human cancers. Nature. 1998;396:643-649.

121. Clements WM, Lowy AM, Groden J. Adenomatous polyposis coli/betacatenin interaction and downstream targets: altered gene expression in gastrointestinal tumors. Clin Colorectal Cancer. 2003;3:113-120.

122. Drier Y, Lawrence MS, Carter SL, et al. Somatic rearrangements across cancer reveal classes of samples with distinct patterns of DNA breakage and rearrangement-induced hypermutability. Genome Res. 2013;23:228-235.

123. Rubinfeld B, Robbins P, El-Gamil M, Albert I, Porfiri E, Polakis P. Stabilization of beta-catenin by genetic defects in melanoma cell lines. Science. 1997;275:1790-1792.

124. Herr P, Hausmann G, Basler K. WNT secretion and signalling in human disease. Trends Mol Med. 2012;18:483-493.

125. Han ZG. Functional genomic studies: insights into the pathogenesis of liver cancer. Annu Rev Genomics Hum Genet. 2012;13:171-205.

126. Sastre-Perona A, Santisteban P. Role of the wnt pathway in thyroid cancer. Front Endocrinol (Lausanne). 2012;3:31.

127. Gatcliffe TA, Monk BJ, Planutis K, Holcombe RF. Wnt signaling in ovarian tumorigenesis. Int J Gynecol Cancer. 2008;18:954-962.

128. Caldwell GM, Jones C, Gensberg K, et al. The Wnt antagonist sFRP1 in colorectal tumorigenesis. Cancer Res. 2004;64:883-888.

129. Lee AY, He B, You L, et al. Expression of the secreted frizzled-related protein gene family is downregulated in human mesothelioma. Oncogene. 2004;23:6672-6676.

130. Suzuki H, Watkins DN, Jair KW, et al. Epigenetic inactivation of SFRP genes allows constitutive WNT signaling in colorectal cancer. Nat Genet. 2004;36:417-422.

131. Fukui T, Kondo M, Ito G, et al. Transcriptional silencing of secreted frizzled related protein 1 (SFRP 1) by promoter hypermethylation in non-small-cell lung cancer. Oncogene. 2005;24:6323-6327.

132. Zou H, Molina JR, Harrington JJ, et al. Aberrant methylation of secreted frizzled-related protein genes in esophageal adenocarcinoma and Barrett's esophagus. Int J Cancer. 2005;116:584-591.

133. Rhee CS, Sen M, Lu D, et al. Wnt and frizzled receptors as potential targets for immunotherapy in head and neck squamous cell carcinomas. Oncogene. 2002;21:6598-6605.

134. Wong SC, Lo SF, Lee KC, Yam JW, Chan JK, Wendy Hsiao WL. Expression of frizzled-related protein and Wnt-signalling molecules in invasive human breast tumours. J Pathol. 2002;196:145-153.

135. Milovanovic T, Planutis K, Nguyen A, et al. Expression of Wnt genes and frizzled 1 and 2 receptors in normal breast epithelium and infiltrating breast carcinoma. Int J Oncol. 2004;25:1337-1342.

136. Okino K, Nagai H, Hatta M, et al. Up-regulation and overproduction of DVL-1, the human counterpart of the Drosophila dishevelled gene, in cervical squamous cell carcinoma. Oncol Rep. 2003;10:1219-1223.

137. Uematsu K, Kanazawa S, You L, et al. Wnt pathway activation in mesothelioma: evidence of Dishevelled overexpression and transcriptional activity of beta-catenin. Cancer Res. 2003;63:4547-4551. 
138. Uematsu K, He B, You L, Xu Z, McCormick F, Jablons DM. Activation of the Wnt pathway in non small cell lung cancer: evidence of dishevelled overexpression. Oncogene. 2003;22:7218-7221.

139. Grosch S, Tegeder I, Niederberger E, Brautigam L, Geisslinger G. COX-2 independent induction of cell cycle arrest and apoptosis in colon cancer cells by the selective COX-2 inhibitor celecoxib. FASEB J. 2001;15:2742-2744.

140. Maier TJ, Janssen A, Schmidt R, Geisslinger G, Grosch S. Targeting the beta-catenin/APC pathway: a novel mechanism to explain the cyclooxygenase-2-independent anticarcinogenic effects of celecoxib in human colon carcinoma cells. FASEB J. 2005;19:1353-1355.

141. Sakoguchi-Okada N, Takahashi-Yanaga F, Fukada K, et al. Celecoxib inhibits the expression of survivin via the suppression of promoter activity in human colon cancer cells. Biochem Pharmacol. 2007;73:1318-1329.

142. Takahashi-Yanaga F, Yoshihara T, Jingushi K, et al. Celecoxib-induced degradation of T-cell factors-1 and -4 in human colon cancer cells. Biochem Biophys Res Commun. 2008;377:1185-1190.

143. Shah S, Hecht A, Pestell R, Byers SW. Trans-repression of betacatenin activity by nuclear receptors. J Biol Chem. 2003;278: 48137-48145.

144. Baron JA, Cole BF, Sandler RS, et al. A randomized trial of aspirin to prevent colorectal adenomas. N Engl J Med. 2003;348:891-899.

145. Sandler RS, Halabi S, Baron JA, et al. A randomized trial of aspirin to prevent colorectal adenomas in patients with previous colorectal cancer. N Engl J Med. 2003;348:883-890.

146. Phillips RK, Wallace MH, Lynch PM, et al. A randomised, double blind, placebo controlled study of celecoxib, a selective cyclooxygenase 2 inhibitor, on duodenal polyposis in familial adenomatous polyposis. Gut. 2002;50:857-860.

147. Jiang Y, Prunier C, Howe PH. The inhibitory effects of Disabled-2 (Dab2) on Wnt signaling are mediated through Axin. Oncogene. 2008;27:1865-1875.

148. Palmer HG, Gonzalez-Sancho JM, Espada J, et al. Vitamin D(3) promotes the differentiation of colon carcinoma cells by the induction of E-cadherin and the inhibition of beta-catenin signaling. J Cell Biol. 2001;154:369-387.

149. Kim J, Zhang X, Rieger-Christ KM, et al. Suppression of Wnt signaling by the green tea compound (-)-epigallocatechin 3-gallate (EGCG) in invasive breast cancer cells. Requirement of the transcriptional repressor HBP1. J Biol Chem. 2006;281:10865-10875.

150. Rao CV, Desai D, Rivenson A, Simi B, Amin S, Reddy BS. Chemoprevention of colon carcinogenesis by phenylethyl-3methylcaffeate. Cancer Res. 1995;55:2310-2315.

151. Jaiswal AS, Marlow BP, Gupta N, Narayan S. Beta-catenin-mediated transactivation and cell-cell adhesion pathways are important in curcumin (diferuylmethane)-induced growth arrest and apoptosis in colon cancer cells. Oncogene. 2002;21:8414-8427.

152. Roccaro AM, Leleu X, Sacco A, et al. Resveratrol exerts antiproliferative activity and induces apoptosis in Waldenstrom's macroglobulinemia. Clin Cancer Res. 2008;14:1849-1858.

153. Morris HR, Taylor GW, Masento MS, Jermyn KA, Kay RR. Chemical structure of the morphogen differentiation inducing factor from Dictyostelium discoideum. Nature. 1987;328:811-814.
154. Mori J, Takahashi-Yanaga F, Miwa Y, et al. Differentiation-inducing factor-1 induces cyclin D1 degradation through the phosphorylation of Thr286 in squamous cell carcinoma. Exp Cell Res. 2005;310:426-433.

155. Chimura T, Launey T, Ito M. Evolutionarily conserved bias of aminoacid usage refines the definition of PDZ-binding motif. BMC Genomics. 2011;12:300.

156. Huang SM, Mishina YM, Liu S, et al. Tankyrase inhibition stabilizes axin and antagonizes Wnt signalling. Nature. 2009;461:614-620.

157. Kadowaki T, Wilder E, Klingensmith J, Zachary K, Perrimon N. The segment polarity gene porcupine encodes a putative multitransmembrane protein involved in Wingless processing. Genes Dev. 1996;10:3116-3128.

158. Voronkov A, Krauss S. Wnt/beta-catenin signaling and small molecule inhibitors. Curr Pharm Des. 2013;19:634-664.

159. Heidel FH, Mar BG, Armstrong SA. Self-renewal related signaling in myeloid leukemia stem cells. Int J Hematol. 2011;94:109-117.

160. Jiang X, Hao HX, Growney JD, et al. Inactivating mutations of RNF43 confer Wnt dependency in pancreatic ductal adenocarcinoma. Proc Natl Acad Sci U S A. 2013;110:12649-12654.

161. Hofmann K. A superfamily of membrane-bound O-acyltransferases with implications for wnt signaling. Trends Biochem Sci. 2000;25:111-112.

162. Gurney A, Axelrod F, Bond CJ, et al. Wnt pathway inhibition via the targeting of Frizzled receptors results in decreased growth and tumorigenicity of human tumors. Proc Natl Acad Sci U S A. 2012;109:11717-11722.

163. Smith DC, Rosen LS Chugh R, et al. First-in-human evaluation of the human monoclonal antibody vantictumab (OMP-18R5; antiFrizzled) targeting the WNT pathway in a phase I study for patients with advanced solid tumors. In: Abstracts of the 2014 Conference of the American Society of Clinical Oncology; May 31-June 4, 2013; Chicago, IL. Abstract 2540.

164. Smith DC, Wells Messersmith MG, Chugh R, et al. A first-in-human Phase 1 study of anti-cancer stem cell (CSC) agent OMP-54F28 (FZD8-Fc) targeting the WNT pathway in patients with advanced solid tumors. In: Abstracts of the 104th Conference of the American Association of Cancer Research; April 6-10, 2013; Washington, DC. Abstract B79.

165. Emami KH, Nguyen C, Ma H, et al. A small molecule inhibitor of beta-catenin/CREB-binding protein transcription [corrected]. Proc Natl Acad Sci U S A. 2004;101:12682-12687.

166. McMillan M, Kahn M. Investigating Wnt signaling: a chemogenomic safari. Drug Discov Today. 2005;10:1467-1474.

167. El-Khoueiry AB, Ning Y, Yang D, et al. A phase I first-in-human study of PRI-724 in patients (pts) with advanced solid tumors. In: Abstracts of the 2014 Conference of the American Society of Clinical Oncology; May 31-June 4, 2013; Chicago, IL. Abstract 2501.

168. Liu J, Pan S, Hsieh MH, et al. Targeting Wnt-driven cancer through the inhibition of Porcupine by LGK974. Proc Natl Acad Sci U S A. 2013;110:20224-20229.
Research and Reports in Biochemistry

\section{Publish your work in this journal}

Research and Reports in Biochemistry is an international, peer-reviewed, open access journal publishing original research, reports, reviews and commentaries on all areas of biochemistry. The manuscript management system is completely online and includes a very quick and fair
Dovepress

peer-review system. Visit http://www.dovepress.com/testimonials.php to read real quotes from published authors. 